\title{
LOS INSTRUMENTOS DE CONTROL PARLAMENTARIO DE LA LEY DE PRESUPUESTOS GENERALES DEL ESTADO
}

\author{
ANA ISABEL MELADO LIROLA \\ Profesora asociada de Derecho Constitucional \\ Universidad de Almería
}
SUMARIO
I. Los condicionamientos generales para el ejercicio del Control Presupuestario.
II. La actividad de control en la formación del Presupuesto.
III. La actividad de control en la ejecución del Presupuesto.

\section{LOS CONDICIONAMIENTOS GENERALES PARA EL EJERCICIO DEL CONTROL PRESUPUESTARIO}

Los modernos Estados democráticos, forjados alrededor de la idea nuclear de Constitución escrita como instrumento para la limitación del Poder, han configurado con el tiempo los principios de control y responsabilidad como elementos consustanciales a la idea misma de democracia. Así, lo propio y sustancial del Estado democrático es el hecho de constituirse y nacer al ordenamiento jurídico como un Estado limitado y, por ende, dotado de unos Poderes públicos responsables y sometidos a control en sus decisiones por los representantes de la voluntad popular.

Las formas y modalidades en que este control se ha ido constitucionalizando son variadas y diversas, en buena medida dependientes de la propia evolución del Estado absoluto al constitucional, y posteriormente profundizadas en las transformaciones habidas hasta desembocar en el Estado democrático y social vigente en nuestras actuales constituciones. En la medida en que el Estado se ha ido democratizado el control se ha sofisticado. Una de las especializaciones de este control ha dado lugar al surgimiento del control político par- 
lamentario sobre el Presupuesto. Así lo entendió Paul Laband cuando en la apertura de la más clásica de sus obras afirmaba que "El Derecho Presupuestario constituye la piedra angular y el fundamento de todos los derechos de la representación popular y ocupa la parte central del Derecho Constitucional».

Se trata, en suma, de controlar la formación del Presupuesto como acto de consentimiento que incide sobre el patrimonio de los particulares y en su histórico y protegido sacrosanto derecho de propiedad ${ }^{1}$. Pero, se trata también de verificar que los actos del Ejecutivo de contenido económico, que son la inmensa mayoría de las decisiones políticas que el Gobierno adopta, se adecuen a las previsiones, cuantías y destino que el Parlamento representativo les haya querido otorgar.

Ello explica que sea abundante la doctrina que existe sobre la temática objeto de nuestro trabajo. La cuestión es tan importante para el Derecho Constitucional que, seguramente, no es ninguna exageración afirmar que la actividad del Parlamento en la aprobación del Presupuesto, posteriormente ligada al control parlamentario sobre su ejecución, acaso haya sido históricamente la más determinante para el desarrollo de la democracia.

En tal sentido podríamos traer a colación la opinión de influyentes tratadistas, como por ejemplo Rubio Llorente, que considera que las instituciones de control parlamentario constituyen "sin exageración alguna, la médula misma de la idea de Constitución, el núcleo esencial del Estado constitucional, puesto que la Constitución no es otra cosa que un instrumento para limitar el poder y garantizar los derechos de los ciudadanos ${ }^{2}$. La existencia misma del concepto de control implica la existencia de una dualidad de sujetos (controlador y controlado) y un parámetro de conducta, un canon de comportamiento a seguir, que de ordinario vendrá impuesto por el criterio del órgano dominante, es decir del sujeto activo del control.

Innecesario resulta recordar que el control jurídico es distinto del político. Mientras que en el primero no existe relación de superioridad del controlador sobre el controlado por cuanto aquel carece de criterio propio y sólo aplica la norma preestablecida, el control político aparece también estructurado jurídicamente pero en él el órgano o actividad controlada debe sujetarse a otro superior criterio cuya regla de conducta no aparece fijada ni preestablecida en lugar alguno.

Sea como fuere, conviene recordar que una buena parte de la doctrina entiende que el debate y la aprobación del Presupuesto no es sino una actividad de control político-parlamentario. Y quizá no le falte razón si consideramos que la aprobación de la Ley de Presupuestos involucra en términos económicos todo un programa político de gobierno. Cuánto gastar y qué planes preferentes atender implica una elección de naturaleza programática y esencialmente po-

1 A. LÓPEZ Y LÓPEZ, El derecho de propiedad. Una 'relectio'. Discurso de ingreso en la Real Academia Sevillana de Legislación y Jurisprudencia. Sevilla. 1999. Pág. 11.

2 F. RUBIO LLORENTE: La forma del Poder. Centro de Estudios Constitucionales. Madrid. 1997. Pág. 243. 
lítica. En la aprobación del Presupuesto la mayoría parlamentaria pone al descubierto sus preferencias de política económica. Y lo mismo sucede con la oposición parlamentaria, bien sea a través del rechazo que le suscita las propuestas de la mayoría, bien sea consiguiendo sacar adelante con sus votos las iniciativas políticas que alternativamente estarían dispuestas a acometer, en el caso de conseguir la dirección política y el ejercicio del gobierno.

Suele ser frecuente en los manuales de Derecho Constitucional hacer referencia a la función financiera de las Cámaras. Y aunque existe un sector doctrinal que opina, por ejemplo, la Profesora P. Biglino Campos, que tal función no representa, en realidad, un cometido distinto al de las otras funciones que tiene atribuidas el Parlamento y que serían las que gozarían de verdadera sustantividad $^{3}$, es, sin embargo, preciso dejar constancia de que la actividad financiera del Parlamento dispone, indudablemente, de características propias y bien definidas.

Hemos convenido en que el Presupuesto es, nada menos, que la expresión numérica de un programa político. Por ello, por la propia relevancia que esta institución alcanza, no es del todo cierto que la tramitación de las leyes financieras no difieran esencialmente de los procedimientos formalizados para el ejercicio de las funciones legislativa y de control, pues disponen en la propia Constitución y en los Reglamentos parlamentarios de un procedimiento legislativo especial y de especiales instrumentos de control, cuya existencia obedece a peculiaridades formales y materiales que hunden sus raíces en profundas y complejas razones históricas.

Cuestión ésta, sin duda, que es preciso poner de manifiesto para subrayar la importancia de una Ley tan específica que, año tras año, contiene la expresión cifrada, conjunta y sistemática de las obligaciones que como máximo se pueden reconocer, de los derechos que se prevean liquidar así como la totalidad de gastos e ingresos del Estado o de la Comunidad Autónoma de que se trate. Se comprenderá, por tanto, la decisiva importancia de la Ley que nos ocupa y los problemas peculiares que plantea la actividad de su control político por el Parlamento, bien de forma inmediata o bien de manera mediata.

Debemos, entonces, partir de la base de que hoy el control parlamentario de la actividad financiera del Gobierno se desarrolla de dos maneras diversas: a) mediante la discusión y aprobación anual de la ley del presupuesto; b) mediante la verificación permanente del respeto a dicha ley, bien directamente en la propia sede parlamentaria, bien indirectamente a través del órgano externo de control o Tribunal de Cuentas.

Sin perder, por tanto, la perspectiva de estos condicionamientos reales, podemos ya abordar el variado arsenal de instrumentos de que dispone el Parlamento — valga decir, la oposición parlamentaria al Gobierno- para efectuar la complicada - pero siempre imprescindible- tarea de control de tan

3 P. BIGLINO CAMPOS: «Parlamento, Presupuesto y Tribunal de Cuentas”. Revista de Derecho Político. N. ${ }^{\circ} 17$, 1996. Pág. 15. 
compleja y prolija norma legal ${ }^{4}$. Sin embargo, con anterioridad quizás convenga efectuar unas someras precisiones sobre algunos de los instrumentos aptos para acometer la tarea de control presupuestario que al Parlamento compete. En efecto, tanto las peticiones de documentación presupuestaria como las preguntas y sesiones informativas para conocer la evolución de los ingresos y gastos son, de ordinario, instrumentos informativos para el control de la acción de gobierno. Así lo pone de manifiesto la práctica diaria y así lo puede constatar cualquier observador de la vida parlamentaria. Y ello no queda desvirtuado por la constatación de que los procedimientos parlamentarios son, generalmente, multifuncionales y, por ende, la información presupuestaria obtenida podría, eventualmente, utilizarse para activar otros procedimientos o para, desde el conocimiento del Estado de gastos y de la evolución de los sectores económicos, abordar la tarea de redactar propuestas alternativas de actuación política o, incluso, elaborar u futuro programa electoral. Y, aunque es más o menos usual en la literatura especializada otorgar la cualidad de instrumentos de control a ciertas técnicas o procedimientos específicos (solicitudes de documentación, preguntas, interpelaciones, sesiones informativas, comisiones de investigación y mociones de censura), es lo cierto que una observación más atenta de la práctica parlamentaria denota que no hay en rigor procedimientos parlamentarios de control porque el control es simplemente una perspectiva desde la que puede analizarse toda la actuación parlamentaria o una función que todo auténtico Parlamento desempeña mediante el ejercicio de toda su actividad. Como afirma el Profesor F. Rubio Llorente, "los procedimientos parlamentarios son siempre multifuncionales, y el análisis de la función de control no puede reducirse, en consecuencia, a procedimientos determinados, sino que ha de tomar como objeto la totalidad de la actuación parlamentaria ${ }^{5}$.

Esta visión del control, entendido en un sentido amplio, tiene el inconveniente de su enfoque unidireccional aunque goza de virtudes innegables desde el punto de vista del análisis práctico. Ello no nos impide comprender que, desde el plano teórico la anterior generalización no ayuda a una adecuada sistematización de los conceptos doctrinales, ni es clarificadora para delimitar la naturaleza de cada uno de los procedimientos parlamentarios ni, en sentido técnico, puede calificarse de actividad de control del Parlamento cosas tan dispares como preguntas, enmiendas a textos legislativos o la propia aprobación del presupuesto. Esta es, justamente, la opinión del Profesor A. Manzella ${ }^{6}$. Sin embargo, es lo cierto que la afirmación de Rubio Llorente bien podría sostenerse desde la observancia del funcionamiento real y cotidiano de la actividad

4 J. CANO BUESO: «El control de los Presupuestos por el Parlamento en España». Nomos. Le actualità nel Diritto. Anno VI. Nuova serie. Revista quatrimestrale. Gennaio-Aprile. Roma. 2001. Reproducido también en "Parlamento y Presupuestos". I Jornadas Parlamentarias de la Asamblea de Madrid. Ed. Asamblea de Madrid. Madrid. 2002.Págs. 203-226

5 F. RUBIO LLORENTE: «El control parlamentario". Revista Parlamentaria de Habla Hispana. N. ${ }^{\circ}$ 1. 1985. Pág. 100.

6 A. MANZELLA: Il Parlamento. Il Mulino. Bologna. 1977. Pág. 355. 
de las Cámaras. Por todo ello, quizás resulte pertinente preguntarse por la naturaleza jurídica de la actividad de control, como paso previo a la descripción de los instrumentos de que el Parlamento dispone para el seguimiento de la aprobación y ejecución del presupuesto. Dicho en términos sumarios, existen dos posiciones al respecto: la más 'ortodoxa' que considera indisolublemente vinculada la evaluación de la actividad gubernamental con la exigencia de responsabilidad. Es la posición, por ejemplo, de F. Santaolalla`; y otra más `innovadora' que separa control y responsabilidad, en la que se ubicaría, por ejemplo, J. García Morillo 8 .

Nuestra posición se incardina en la segunda de las manifestaciones expresadas. De ahí que, por cuanto no toda actividad de control desemboca, inexorablemente, en la exigencia de responsabilidad, podamos expresar nuestras dudas acerca de la utilidad práctica de separar el concepto de control, por un lado, y el de información o inspección, por otro. Y ello porque las actividades que ambos procedimientos desenvuelven terminan centrándose en un examen, evaluación debate y crítica de la acción gubernamental.

Vistas así las cosas, es evidente que la actividad informativa es un paso previo e imprescindible para el posterior ejercicio del control, pues aunque aquélla pueda agotarse en sí misma, lo usual es que sobre los datos obtenidos se realice una actividad de valoración y juicio de carácter crítico. En tal sentido es conveniente precisar que los actos de control parlamentario no proceden sólo —ni siquiera, principalmente- de las Cámaras y de sus órganos, sino sobre todo de los parlamentarios y de los Grupos Parlamentarios en que se integran. Y ello porque el carácter representativo no sólo se predica del Órgano sino también de sus miembros individualmente considerados (art. 67.2 CE), lo que explica que se confiera a éstos diversas posibilidades de actuación para el cumplimiento de sus funciones parlamentarias. Ello ha permitido que se pueda distinguir por la doctrina, en concreto por el Profesor M. Aragón, entre control por el Parlamento y control en el Parlamento'. Mientras que el primero se materializa en actos que expresan la voluntad de la Cámara, el segundo se manifiesta a través de diversas actividades individuales de los sujetos parlamentarios (Diputados y Grupos) como medios de control de la minoría que pueden activarse, incluso, contra la voluntad de la mayoría (preguntas, interpelaciones, sesiones informativas etc.).

El Profesor A. Rodríguez Bereijo ha sistematizado con claridad algunas de las causas que, a su juicio, explicarían las dificultades que el Parlamento encuentra para efectuar un adecuado control del Presupuesto ${ }^{10}$ :

7 F. SANTAOLALLA LOPEZ: Derecho Parlamentario Español. Editora Nacional. Madrid, 1984.

8 J. GARCIA MORILLO: El control parlamentario del Gobierno. Publicaciones del Congreso de los Diputados. Monografías. Madrid, 1985.

9 M. ARAGON REYES: Gobierno y Cortes. Instituto de Estudios Económicos. Madrid, 1994. Págs. 24 y 25.

10 A. RODRIGUEZ BEREIJ: El control parlamentario de la política económica. Op. Cit. Págs. 132 y ss. 
1. ${ }^{\text {) }}$ El desequilibrio actual entre los Poderes del Estado, a favor de un Ejecutivo fuerte y un Parlamento débil, dependiente para su información del Ejecutivo y excesivamente "racionalizado".

2. ${ }^{a}$ El propio contenido del Presupuesto, que en buena parte incluye autorizaciones de créditos ya previamente comprometidos por el Parlamento mediante decisiones que generan gastos (creación se servicios nuevos, por ejemplo) o bien se han adquirido compromisos de carácter plurianual. Ello propicia la generación de un "gasto público consolidado" que el Parlamento viene abocado a aprobar. De esta forma, la Ley de Presupuestos se ha convertido en una ley de ejecución de gastos comprometidos en otras leyes sustantivas de carácter extrapresupuestario. Esta suerte de predeterminación de las consignaciones presupuestarias dota de gran rigidez al Proyecto de Ley de Presupuestos y limita y hasta coarta la soberanía financiera del Parlamento.

3. a) La existencia de un "sector público sumergido", integrado por empresas públicas actuando en régimen de Derecho Privado y que pretenden mediante semejante < huida $>$ del Derecho Público escapar del pertinente control parlamentario.

4. ${ }^{\text {a) }}$ La existencia de fondos económicos muy importantes que integran la política económica y cuya vida se desenvuelve, en buena medida, al margen de los Presupuestos Generales del Estado. Entre ellos habría que incluir a la regulación de la política monetaria que llevan a término el Banco Europeo y el Banco de España, la financiación del déficit a través del endeudamiento público, mediante la emisión de Deuda Pública, Pagarés y Bonos del Tesoro etc.

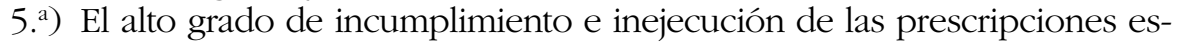
tablecidas en el Presupuesto. En efecto, es bastante usual que, por ineficacia en la gestión o por una mala organización de los recursos administrativos, las consignaciones presupuestarias relativas, sobre todo, a gastos de inversión o de capital no se ejecuten por encima de un 30\% del montante de gastos programados y autorizados.

6. $\left.{ }^{2}\right)$ La carencia de instrumentos adecuados en el interior de las Cámaras para examinar con profundidad y rigor el Presupuesto. La inexistencia de Cuerpos funcionariales especializados en materia económica y la ausencia de órganos dónde poder encontrar asesoramiento solvente y objetivo sobre estas cuestiones dificultan extraordinariamente la tarea de control del Presupuesto. Para facilitar el objetivo de controlar las cuentas públicas deberían de generalizarse en los Parlamentos las «Oficinas de Control Presupuestario", que siguiendo el modelo del Congreso norteamericano, se trata de un staff técnico al servicio de los parlamentarios y que puede, además de facilitar el debate y el posterior control, tender puentes de diálogo entre Gobierno y Parlamento de cara a una recíproca colaboración en la configuración y ejecución del Presupuesto. 
7.a) La inadecuación de la regulación del procedimiento legislativo especial de discusión y aprobación de los Presupuestos, que convierten la sesión en interminable y farragosa, máxime si tenemos en cuenta nuestro sistema parlamentario bicameral.

Dicho cuanto antecede, a efectos sistemáticos de una mejor comprensión de la materia que nos ocupa, distinguiremos entre actividad de control en origen que se corresponde con el proceso de formación del Presupuesto ex ante y la actividad de control en la fase de ejecución expost.

\section{LA ACTIVIDAD DE CONTROL EN LA FORMACION DEL PRESUPUESTO}

Una lectura somera de los preceptos constitucionales nos pone de manifiesto que al Gobierno corresponde la dirección de la política económica y al Parlamento compete aprobar los fondos necesarios y controlar la ejecución de los mismos. La función financiera viene, entonces, referida a la potestad de las Cortes Generales para fijar la forma de determinar los ingresos y gastos del Estado. Dentro de esta genérica atribución es preciso distinguir la potestad tributaria y la potestad presupuestaria:

A) La 'potestad tributaria' alude a la capacidad de imponer tributos que graven los ingresos y propiedades de las personas. La necesidad de obtener el consentimiento de los ciudadanos para imponer tributos implantó bien pronto el principio de legalidad tributaria, como punto de llegada de una larga lucha porque los representantes de la Nación decidiesen sobre los ingresos del Estado, decisión que debía ubicarse en el Parlamento por cuanto, como ha quedado dicho, afectaba al trascendental derecho de propiedad.

Nuestra suprema norma, haciéndose eco de esta conquista del moderno constitucionalismo, acoge el principio de legalidad tributaria en los artículos 31.3 y 133.1. Según el primero de ellos, todos los ciudadanos vienen obligados al sostenimiento de los gastos públicos de acuerdo a su capacidad económica, a través de un sistema tributario que se base en los principios de igualdad y progresividad y, en todo caso, desprovisto de carácter confiscatorio. La capacidad originaria para establecer tributos viene atribuida exclusivamente al Estado - léase Cortes Generales- mediante Ley. La propia Constitución prohíbe el ejercicio de la potestad tributaria a través de la Ley de Presupuestos, que no puede crear tributos nuevos sino sólo modificar los existentes previstos en una ley sustantiva anterior. Mucho se ha discutido acerca de los límites del Decreto-Ley para entrar a regular estas materias. Sabido es que en nuestro ordenamiento constitucional el artículo 86.1 establece que las medidas legislativas provisionales que puede dictar el Gobierno, en casos de extraordinaria y urgente necesidad "no podrán afectar a los derechos, deberes y libertades de los ciudadanos regulados en el Título I" de la propia Constitución. Y sabido es que la formulación constitucional del artículo 31.1 no es una declaración progra- 
mática sino la consagración de un verdadero mandato jurídico, que es fuente de derechos y obligaciones, y del que se deriva directamente un deber para los ciudadanos de contribuir al sostenimiento y financiación de los gastos públicos.

Pues bien, en opinión de nuestro Tribunal Constitucional, en la importante STC 182/1997, el Decreto-Ley no puede alterar ni el régimen general ni los elementos esenciales del deber de contribuir. Sin embargo, "no queda absolutamente impedida la utilización del Decreto-Ley en materia tributaria, cuando concurre el supuesto habilitante, como instrumento normativo del Gobierno al servicio de los objetivos de la política económica. Ahora bien, será preciso tener en cuenta en cada caso en qué tributo concreto incide el Decreto-Ley, que elementos del mismo resultan alterados por este excepcional modo de producción normativa y, en fin, cual es la naturaleza y alcance de la concreta regulación de que se trate" (FJ 7). Y finalmente concluye que "del hecho de que la materia tributaria esté sujeta al principio de reserva de ley (arts. 31.3 y 133.1 y 3 CE) y de que dicha reserva tenga carácter relativo y no absoluto, al entenderse referida al establecimiento de los tributos y a su esencial configuración, pero no, en cambio, a cualquier tipo de modificación tributaria (STC 6/1983, FJ 4), no se deriva necesariamente que se encuentre excluida del ámbito de regulación del Decreto-Ley, que podrá penetrar en la materia tributaria siempre que se den los requisitos constitucionales del presupuesto habilitante y no <afecte>, en el sentido constitucional del término, a las materias excluidas. Límite material que no viene señalado por la reserva de Ley, de modo que lo reservado a la Ley por el art. 31.3 CE tenga que coincidir necesariamente con lo que haya de entender por <afectar> al deber constitucional de contribuir al sostenimiento de los gastos públicos del art. 31.1 CE» (F. J. 8).

Por lo demás, y todavía en relación con el posible uso del Decreto-Ley en materia presupuestaria, hay que recordar, como lo hace el Tribunal Constitucional, que "la devolución al Gobierno de los Presupuestos no fundamenta la extraordinaria y urgente necesidad" para dictar normas tributarias a través de esta figura jurídica. (STC 137/2003, FJ 5).

B) La 'potestad presupuestaria', por su parte, alude a la capacidad del Parlamento para aprobar periódicamente la previsión de ingresos y la autorización de gastos para subvenir a la realización de la política económica del Estado. Ello se realiza a través de la elaboración y aprobación del Presupuesto General, basado en los principios de legalidad, especialidad, unidad y anualidad. La Constitución Española dedica a la Ley de Presupuestos un largo y prolijo artículo 134, que se abre con una cláusula atributiva fundamental: "Corresponde al Gobierno la elaboración de los Presupuestos Generales del Estado y a las Cortes Generales su examen, enmienda y aprobación". Y similares preceptos, si acaso más completos, dedican los Estatutos de Autonomía a esta función.

Su tramitación en las Cámaras se rige por un procedimiento legislativo especial. Una vez remitido el Proyecto de Ley al Congreso de los Diputados y ordenada su publicación por la Mesa, se inicia el procedimiento parlamentario con la comparecencia de los distintos responsables de las secciones presupuestarias, a fin de ilustrar a los diputados sobre los objetivos y fines de los 
programas sobre los que las distintas autoridades comparecientes ostentan responsabilidad. El debate se referirá tanto al articulado como al estado de autorización de gastos. El Gobierno viene, además, obligado a presentar el Proyecto de Ley de Presupuestos ante el Congreso de los Diputados al menos tres meses antes de la expiración de los del año anterior. Por su importancia, goza de preferencia general en la tramitación respecto de los restantes trabajos de las Cámaras. Las enmiendas de totalidad al mismo sólo podrán postular la devolución de aquél al Gobierno por cuanto éste ostenta el monopolio de la elaboración y presentación de los Presupuestos ante el Congreso. En alguna Comunidad Autónoma, cual es el caso de Andalucía, también son consideradas enmiendas a la totalidad al Presupuesto las que impliquen la impugnación completa de una sección presupuestaria. El debate de totalidad tendrá lugar en el Pleno de la Cámara y al término del mismo quedarán fijadas tanto la cifra global del Presupuesto como la de cada una de las secciones, que no podrán en lo sucesivo ser alteradas, salvo acuerdo entre la Cámara y el Gobierno.

El texto, con su documentación aneja, se remite a la Comisión de Presupuestos para su ulterior tramitación como un proyecto de ley ordinario, con la expresa salvedad de que las enmiendas que supongan aumento de crédito en algún concepto únicamente podrán ser tramitadas si proponen una baja de igual cuantía en la misma sección. Con similar lógica, las enmiendas que supongan minoración de ingresos requerirán la conformidad del Gobierno para su tramitación. En este último punto resulta criticable que los Reglamentos parlamentarios hayan ido mucho más lejos que el artículo 134.6 CE, habiendo extendido estas limitaciones al derecho de modificación o enmienda (las llamadas enmiendas 'constructivas'), no sobre un presupuesto en vigor (como parece dar a entender el mencionado precepto constitucional) sino, también, sobre un proyecto de ley de presupuestos que se está debatiendo en la Cámara. Ello no puede tener otro entendimiento que la consideración por el Reglamento del Congreso de la necesidad de salvaguardar el equilibrio presupuestario del documento en discusión. Se trataría, entonces, de impedir el déficit presupuestario que, contemplado desde el liberalismo conservador como un mal endémico de nuestro tiempo, es, sin embargo, una opción económica perfectamente legítima desde políticas expansivas del gasto de marcada matriz progresista.

A lo largo de las sesiones en Comisión el debate del Proyecto de Ley de Presupuestos se referirá al texto articulado y al estado de autorización de gastos y el debate final en el Pleno del Congreso diferenciará, por un lado, el conjunto del articulado de la Ley y, por otro, cada una de las Secciones presupuestarias. En el Senado rigen las mismas especialidades de tramitación que en el Congreso, con la particularidad de que la enmienda que implique la impugnación completa de una sección presupuestaria se tramitará como una propuesta de veto. Estas son las más importantes especialidades de la tramitación del Proyecto de Ley de Presupuestos que contienen los Reglamentos parlamentarios españoles, tanto de los órganos integrantes de las Cortes Generales (Con- 
greso de los Diputados y Senado) como de las Asambleas Legislativas de las diferentes Comunidades Autónomas.

Una primera cuestión metodológica, aunque obvia, es preciso poner de manifiesto. Por cuanto nuestro trabajo se circunscribe al control de los Presupuestos por el Parlamento, queda fuera del objeto de estudio el proceso que concluye en la formación del anteproyecto de ley que acaece en sede gubernamental. Nuestra tarea se contrae, por consiguiente, a cuanta actividad pueda considerarse de control a partir de la entrada del Proyecto de Ley de Presupuestos en el Registro General de la Cámara.

Para considerar la actividad de control en el origen podríamos partir de la idea de que, tal como hemos expuesto más atrás, no existen en rigor procedimientos parlamentarios de control, en el sentido de que el control es una perspectiva general desde la que puede contemplarse la actividad parlamentaria en su conjunto, según la conocida tesis de F. Rubio Llorente. Utilizando instrumentalmente esta opinión, que no es desde luego pacífica, la propia multifuncionalidad de los procedimientos parlamentarios nos llevaría a concluir que la actividad desarrollada en el seno del procedimiento legislativo, en orden a la aprobación de la ley de presupuestos, representa ya, en sí misma, una función de control que se manifiesta en diversas y sucesivas fases:

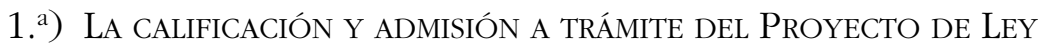 de Presupuestos por la Mesa del Congreso de los Diputados}

El artículo 134.3 de la Constitución establece que «El Gobierno deberá presentar ante el Congreso de los Diputados los Presupuestos Generales del Estado". En consecuencia, una inicial actividad de control acaece de inmediato en el ejercicio de la función que el Reglamento parlamentario atribuye a la Mesa de la Cámara en orden a la calificación y admisión a trámite de los escritos e iniciativas parlamentarias. En consecuencia, en este momento procedimental, que es cabecera y origen de todo caminar en el interior de la Cámara, el máximo órgano de gobierno interior verificará el cumplimiento de los requisitos formales del texto remitido, tanto los generales aplicables a cualquier proyecto de ley (que haya sido aprobado por el Consejo de Ministros y que vayan acompañados de una exposición de motivos y de los antecedentes necesarios para pronunciarse sobre ellos, en los términos establecidos por el artículo $88 \mathrm{CE}$ ), como los especiales previstos en los artículos 134 y 135 CE y 37 de la ley 47/2003 General Presupuestaria (en adelante, LGP), anualidad, documentos que lo integran, contenido de los mismos etc...

Varias cuestiones es necesario comentar en este punto. En primer lugar hay que poner de manifiesto que el texto constitucional no determina la forma de elaboración de los Presupuestos Generales del Estado ni el número y clase de documentos que deban presentarse o unirse a aquél en el momento de la presentación ante las Cortes. Es cierto que cabe extraer de la propia Constitución (artículo 88) que el Proyecto de Ley de Presupuestos, como todo proyecto 
que el Gobierno remita al Parlamento, debe ir acompañado de la correspondiente exposición de motivos y de los antecedentes necesarios para poderse pronunciar la Cámara. La vaguedad de este precepto, desde luego, no exime, obviamente de su cumplimiento. Sobre este asunto de los antecedentes necesarios que deben acompañar a cualquier proyecto de ley tuvo ocasión de pronunciarse el Tribunal Constitucional en su ya lejana Sentencia 108/1986 al entender que la ausencia de un determinado antecedente sólo tendrá trascendencia si se hubiese privado a las Cámaras de un elemento de juicio necesario para su decisión, necesidad que corresponde apreciar a las propias Cámaras (en todo caso, a las Mesas), sin que el Tribunal Constitucional pueda interferirse en la valoración de la relevancia que un elemento de juicio tuvo para los parlamentarios. Tales omisiones de documentación sólo cobran, pues, relevancia si menoscaban los derechos de los Diputados o de los Grupos Parlamentarios, lesión que debe entenderse inexistente cuando no media protesta de los parlamentarios o Grupos o no la aprecia la Mesa en el acto de calificación y admisión a trámite del Proyecto de Ley. (F. J. 3. ${ }^{\circ}$ ).

A esta evidente falta de concreción constitucional habría que añadir la propia de los Reglamentos parlamentarios que no ayudan demasiado al respecto. En efecto, el Reglamento del Congreso de los Diputados contiene una breve alusión al manifestar que «El debate del Presupuesto se referirá al articulado y al estado de autorización de gastos. Todo ello sin perjuicio del estudio de otros documentos que deban acompañarse a aquel, (Art. 134.2 RCD). Por su parte, el reglamento del Senado es un poco más explícito sobre este asunto: «El debate del Presupuesto abarcará el examen del articulado y del estado de autorización de gastos, sin perjuicio del estudio de otros documentos que, de acuerdo con la Ley General Presupuestaria, deban acompañar a aquel, (Art. 150.1 RS). Es, por consiguiente, la Ley la que viene en auxilio de la Constitución y el Reglamento parlamentario para fijar el soporte documental mínimo que debe acompañar al Proyecto de Ley de Presupuestos en su remisión al Parlamento, y cuyo cumplimiento corresponde apreciar a la Mesa del Congreso de los Diputados en el momento de la calificación y admisión a trámite del Proyecto de Ley.

Admitido a trámite el Proyecto de Ley, la Mesa ordenará la publicación del Proyecto de Ley en el Boletín correspondiente. La norma debe ser publicada en su totalidad, aunque en el caso del Proyecto de Ley de Presupuestos es usual que buena parte de la documentación que se acompaña se ponga simplemente a disposición de los parlamentarios Como afirma el Tribunal Constitucional, la publicidad es un elemento inherente a la seguridad jurídica (STC 235/2000, F. J. 8), "principio éste básico del Ordenamiento jurídico que implica la exigencia de que las normas sean dadas a conocer públicamente mediante su inclusión en los boletines oficiales correspondientes" (STC 3/2003, F. J. 10).

Por lo demás, los Reglamentos parlamentarios acogen el principio de preferencia general en la tramitación de que goza el Proyecto de Ley de Presupuestos respecto a los demás trabajos de la Cámara (art. 133.2 RCD), lo que no es sino una manifestación de la importancia del texto cuyo contenido es nada 
menos que la expresión cifrada, conjunta y sistemática de la política económica del Gobierno para una anualidad.

Para Mortati el principio de anualidad presupuestaria "corresponde al intento de hacer intervenir al Parlamento a intervalos no demasiado largos en la apreciación de la correspondencia del plan financiero al programa de gobierno que está en la base de la relación fiduciaria entre dos órganos " ${ }^{11}$. Ello conecta con las previsiones constitucionales de que el Proyecto de Ley de Presupuestos deba presentarse por el Gobierno ante el Congreso al menos tres meses antes de la expiración de los del año anterior y con la previsión de la prórroga automática de los Presupuestos anteriores si los nuevos no se aprobasen antes del primer día del ejercicio económico correspondiente (art. 134.3 y 4 CE en relación con el art. 38 LGP).

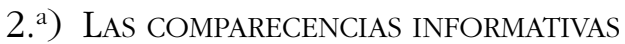

Hace ya algunos años señalaba C. J. Friedrich que "hay un campo determinado de la actividad parlamentaria en que se suele reconocer generalmente el valor del sistema de comité; es el terreno del control financiero y, específicamente, más aún del presupuestario" ${ }^{12}$. Y así, el autor se refería a cómo en Estados Unidos, en Gran Bretaña o en Francia el control de una partida presupuestaria derivaba, generalmente, en un debate de política general en un comité concreto. La experiencia española, tras la entrada en vigor de la Constitución de 1978, se mueve en idéntico sentido, sobre todo desde que se ha instaurado el uso parlamentario de que la Comisión de Presupuestos la presida un distinguido miembro del primer partido de la oposición.

De esta manera, en nuestro actual Derecho Parlamentario la práctica ha acuñado una costumbre cuya manifestación más genuina se mueve también en la órbita del control. Se trata de una serie de 'comparecencias' de los titulares de los distintos Departamentos ministeriales y de altos cargos de la Administración ante la Comisión correspondiente. Estas sesiones se programan por la Mesa junto al calendario general de tramitación del Proyecto de Ley y la experiencia enseña que las mismas sirven para que los Grupos Parlamentarios de la oposición cuestionen los programas económicos que se les presentan y el contenido político de la acción de gobierno que de los mismos se deriva. A este respecto cobra importancia, a modo de opiniones autorizados para los diputados, la presencia ante la Comisión de los representantes de los agentes económicos y sociales, que obviamente tienen bastante que decir al respecto en aras de un posterior diálogo social.

11 C. MORTATI: Istituzioni di Diritto Pubblico. Op. Cit. Pág. 67.

12 C. J. FRIEDRICH: Gobierno constitucional y democracia. Tomo II. Instituto de Estudios Políticos. Madrid, 1975. Pág 176. 


\section{3. a ) La Presentación de enmiendas al Proyecto de Ley de Presupuestos}

Un tercer momento de la actividad de control se manifiesta en el trámite de presentación y defensa de las 'enmiendas' formuladas. La cuestión viene en el fondo conectada a la naturaleza jurídica de la Ley de Presupuestos. En líneas generales hay que considerar que, estando atribuida al Parlamento la capacidad de criticar la actividad de las Administraciones Públicas y de incidir sobre la potestad de dirección política, es de lógica jurídica y política para el sistema que el Parlamento pueda expresar sus opiniones y observaciones concretadas en forma de enmiendas al texto articulado y a las propias consignaciones integradas en las secciones presupuestarias. Se comprenderá fácilmente que esta capacidad de enmienda no puede devenir en una simple discusión académica más o menos técnica. Antes al contrario, como dice Jezé, debe alumbrar una decisión política que concluya con un concreto mandato al Gobierno para que éste ponga en ejecución el programa político propuesto por la mayoría parlamentaria ${ }^{13}$.

El desconocimiento del poder de enmendar por parte del Parlamento no favorecería, ciertamente, el principio de estabilidad política. Y ello es así porque de lo contrario, si el Parlamento no pudiese modular y alterar el contenido de las consignaciones presupuestadas, se pondría a las Cámaras en la disyuntiva de tener que aprobar o rechazar en bloque el Presupuesto propuesto por el Gobierno con las subsiguientes consecuencias de orden político y de orden constitucional.

Ciertamente, no han faltado voces que en el marco del debate doctrinal han tomado posiciones a favor de negar el poder parlamentario de enmienda sobre el presupuesto, justamente por el argumento de atribuir el valor de un mero acto de administración a la aprobación parlamentaria del Presupuesto. Sin embargo, puesto que de hecho las enmiendas al Presupuesto existen también en países que aceptan la naturaleza de ley formal del Presupuesto, se necesita, quizás, efectuar alguna precisión al respecto en el siguiente sentido:

En primer lugar, las enmiendas mismas pueden considerarse un acto del poder legislativo, si se admite la naturaleza sustancial de las leyes de presupuestos. Pero, en segundo lugar, también podrían entenderse las enmiendas como un acto del Gobierno en orden a introducir las sugerencias y modificaciones propuestas por al Parlamento en orden a aprobar el Presupuesto, si se admite la naturaleza formal de la ley misma. Como puede apreciarse, se trata en cualquier caso de enmiendas y modificaciones que concurren a un preciso fin, cual es determinar la dirección política propuesta por el Gobierno y aprobada por el Parlamento.

Sea como fuere, conviene no perder de vista que las enmiendas propuestas por el Parlamento a las consignaciones presupuestarias no pueden ir dirigidas a modificar las leyes que sustentan el bloque de ingresos públicos de que se nutren los presupuestos. Dicho en otras palabras, la ley presupuestaria no debe crear tributos y sólo podrá modificarlos cuando una ley sustantiva así lo

13 JÈZE. Théorie générale du budget. París, 1922. Pág. 52. 
determine con toda claridad. De lo antes dicho deriva el hecho de que la presentación de enmiendas por el Parlamento a los Presupuestos tiene consecuencias y alcances distintos según se trate de la afectación de los ingresos o de los gastos y, para éstos últimos, según su naturaleza y compromiso sea obligatorio o discrecional.

Pero, existe otro orden de cuestiones de naturaleza claramente constitucional y que en este punto debemos resaltar. En efecto; la tramitación del Presupuesto en la Cámara, particularmente en las fases de examen y enmienda, son expresivas del pluralismo político que acoge nuestra Constitución como valor superior del ordenamiento jurídico (art. 1.1 CE). El sistema de producción de normas legales, incluida la Ley de Presupuestos, es en nuestros días, primordialmente, una instancia de integración de voluntades, de expresión de alternativas diversas, de propuesta, participación y negociación para incidir en el programa económico que pretende aplicar el Gobierno. Pero, también de control y crítica de quien tiene constitucionalmente conferida la responsabilidad de gobernar y proponer. No otro significado puede atribuirse al amplio número de propuestas de enmienda que este tipo de Proyecto de Ley suele recibir, por más que un problema distinto sea la mayor o menor permeabilidad de la mayoría a la hora de incorporar dichas enmiendas, situación que viene afectada, generalmente, por la correlación de fuerzas existente en cada momento en la Cámara.

Pero, es ya en este momento del procedimiento donde empieza a ponerse de manifiesto el desequilibrio de poderes a favor del Gobierno. No se trata sólo de que el Poder Ejecutivo, como hemos dicho, ostente el monopolio en la elaboración y presentación del Proyecto de Ley de Presupuesto, por lo que sólo es susceptible de enmienda de totalidad en la que se solicite la devolución. Se trata, también, de que, una vez fijadas las cuantías globales de los estados de los Presupuestos en el debate de totalidad, las enmiendas parciales que supongan aumento de créditos en algún concepto sólo podrán ser admitidas a trámite si proponen una baja de igual cuantía en la misma sección. Todo ello en aras de no alterar el equilibrio presupuestario, pues si éste peligra a través de enmiendas que supongan minoración de ingresos, dichas enmiendas sólo pueden admitirse si el Gobierno otorga la conformidad a su tramitación.

\section{4. $\left.{ }^{a}\right)$ La aprobación autónOma de los Presupuestos de las Cortes GENERALES}

Ha escrito el Profesor J. Cano Bueso que el principio de autonormatividad de las Cámaras es la potestad de que gozan las Asambleas legislativas para dictarse a sí mismas sus propias normas de funcionamiento interno y se fundamenta en la prerrogativa constitucional conocida como autonomía parlamentaria $^{14}$. Se trataría, en definitiva, del conjunto de facultades de que disponen las

14 J. CANO Bueso, Derecho Constitucional. Vol. II. F. Balaguer Callejón (Coord.). Tecnos. Madrid. 1999. Pág. 353. 
Asambleas legislativas para regular sus normas de funcionamiento interno y gestionar sus propios asuntos, de forma que el Parlamento pueda cumplir autónomamente el conjunto de tareas asignadas por la Constitución. Entre esas facultades instrumentales, ordenadas al cumplimiento de unos fines, y como una expresión del principio de autonormatividad de las Cámaras, se encuentra él principio de autonomía presupuestaria. Se trata, pues, de la capacidad que tiene el Parlamento para elaborar y aprobar su propio Presupuesto sin intervención alguna del Gobierno ${ }^{15}$.

Pues bien, a pesar de lo dispuesto en el artículo 134 de la Constitución, y como excepción al mismo, el artículo 72.1 también de la suprema norma establece que "las Cámaras (...) aprueban autónomamente sus Presupuestos...". Ello significa, lisa y llanamente, que lo hacen sin la intervención del Gobierno. Se trataría, entonces, de un «imperativo constitucional, por utilizar las palabras de L. M. Diez Picazo ${ }^{16}$. La decisión acerca de cuanto y en qué han de gastar las Cámaras para proveer a sus gastos de funcionamiento, a fin de dar pleno cumplimiento al ejercicio de sus facultades constitucionales, se mueve pues al margen de la voluntad del Gobierno, a quien las Cortes imponen, libremente, su voluntad en materia de administración y gasto. Piénsese que si la decisión de la cuantía y el destino del presupuesto de gastos del Parlamento fuese disponible para el Gobierno, podría éste por conducto de la <asfixia presupuestaria> impedir el ejercicio de las potestades y funciones constitucionalmente asignadas a las Cámaras; o, lo que alcanza objetivos similares mediante la simple realización de éstas facultades en plena penuria de medios materiales y personales.

Todo lo anterior significa, tal como ha observado el Profesor C. Albiñana, que la elaboración y aprobación de los Presupuestos de las Cámaras constituye una "pieza separada" de los Presupuestos Generales del Estado y al margen por completo del Gobierno, pues si se admitiese otra interpretación quedaría vacío de contenido el artículo 72.1 de la Constitución. ${ }^{17}$. Nos encontramos, pues, ante una elaboración presupuestaria propia que, una vez definitivamente aprobada por el correspondiente órgano parlamentario, se traslada al Ministerio de Economía y Hacienda para su incorporación a los Presupuestos Generales del Estado.

Como no podía ser de otra manera, dándose en nuestro sistema las características básicas de un modelo parlamentario de carácter bicameral, el principio de autonomía presupuestaria tiene su correspondiente reflejo en los Reglamentos parlamentarios. Así, en el del Congreso de los Diputados el artículo 31.1 establece que "Corresponden a la Mesa las siguientes funciones: (...) 2. ${ }^{\text {a }}$ Elaborar el proyecto de Presupuesto del Congreso de los Diputados, dirigir y con-

15 Vid. J. CANO BUESO, «El principio de autormatividad de las Cámaras y la naturaleza jurídica del Reglamento parlamentario". Revista de estudios políticos. N. ${ }^{\circ}$ 40, Julio-Agosto, 1984.

16 L. M. DIEZ-PICAZO: "La autonomía administrativa de las Cámaras parlamentarias". Cuadernos de los Studia Albortiana. Zaragoza, 1985. Pág. 128.

17 C. ALNIÑANA GARCIA-QUINTANA: "Comentario al artículo 134 de la Constitución", en O. Alzaga Villaamil: Comentarios a la Constitución Española de 1978. Cortes Generales/Edersa, Madrid, 1998. Pág. 313. 
trolar su ejecución y presentar ante el Pleno de la Cámara, al final de cada ejercicio, un informe acerca de su cumplimiento". Por su parte, el Reglamento del Senado venía atribuyendo a la Comisión de Gobierno Interior "elaborar el Presupuesto de gastos del Senado. Desaparecida esta Comisión en la reforma del Reglamento de 1994, es la Mesa del Senado la que en virtud de la competencia general residual que el Reglamento le confiere, viene elaborando el Proyecto de Presupuesto de la Cámara.

Como resulta evidente de cuanto antecede, mientras que las Cortes Generales gozan de autonomía para la elaboración y aprobación de su Presupuesto, este mismo principio no puede ser invocado ni por el Poder Judicial ni por el Gobierno, que en esta materia se encuentra formalmente vinculado a la aprobación del correspondiente proyecto de ley por el Parlamento, siguiendo la clásica posición subordinada del Gobierno al Parlamento formalmente subsistente desde la construcción del sistema parlamentario de gobierno y la vigencia del principio de legalidad presupuestaria.

Faltaría por dilucidar si en la elaboración y aprobación de sus propios Presupuestos, el Congreso y el Senado se atienen en sus importes totales a los crecimientos y a las magnitudes que para el sector público estatal establece el Gobierno en su función de dirección política estatal. En este sentido hay que indicar que las Cámaras, en la práctica, no se suelen vincular a estas directrices, comportamiento que ha sido criticado por C. Albiñaña al entender que de no darse esta vinculación, entiendo que se ha atribuido una prerrogativa sin fundamento apreciable a las Cámaras, que desembocará en remuneraciones, compras de bienes etc. en desacuerdo con las que otros órganos del Estado tengan a su cargo" ${ }^{18}$.

En puridad constitucional no es posible estar de acuerdo con la afirmación de este prestigioso hacendista, pues de observarse esta vinculación en sentido jurídico estaríamos vaciando de contenido el principio de autonomía presupuestaria garantizado a las Cámaras por el artículo 72.1 de la Constitución. Por lo demás, la posición constitucional de las Cortes Generales, que representan al pueblo español y encarnan la soberanía popular, no puede ser comparada en modo alguno con los restantes órganos constitucionales o de relevancia constitucional. Distinto es que, por razones de oportunidad política, la prudencia de los órganos de dirección parlamentaria consideren conveniente seguir las directrices macroeconómicas en materia de gasto, pero desde la perspectiva jurídico-constitucional en forma alguna le es exigible tal comportamiento a las Cámaras, que pueden y deben desenvolver su comportamiento presupuestario con plena libertad.

En relación directa con el problema anterior, una última cuestión cabría plantear en este punto. Nos referimos a la posible colisión entre el principio de autonomía presupuestaria y el principio de unidad presupuestaria, que es también un principio constitucional acogido en el artículo 134.2 de la Constitución

18 C. ALBIÑAÑA GARCIA QUINTANA: “Comentario al artículo 134 de la Constitución”. Op. Cit. Págs. 313 y 314. 
cuando establece que "Los Presupuestos Generales del Estado (...) incluirán la totalidad de los gastos e ingresos del sector público estatal.... Esta aparente colisión de principios constitucionales (el de autonomía presupuestaria de las Cámaras y el de unidad presupuestaria) viene solventado por la LGP. En efecto, a los fines de dar comienzo al procedimiento de elaboración del Presupuesto, el artículo 36 de la precitada Ley establece que " Los Órganos constitucionales, los Departamentos ministeriales y los demás órganos del Estado con dotaciones diferenciadas en los Presupuestos Generales del Estado remitirán al Ministerio de Hacienda, antes del 1 de mayo de cada año, sus correspondientes estados de gastos, debidamente documentados y ajustados a las leyes que sean de aplicación y a las directrices aprobadas por el Gobierno".

Es cierto que en la expresión "Órganos constitucionales" (Órganos superiores del Estado", en la terminología anterior), entendida como contrapuesta a "Departamentos ministeriales", cabría incluir, naturalmente, a las Cortes Generales. Las Cámaras deben, pues, enviar, antes de la fecha indicada, su documento presupuestario autónomamente elaborado, a fin de dar cumplimiento al principio constitucional de unidad presupuestaria. Y aquí se plantea de nuevo el problema, más atrás apuntado, de si el Gobierno, a quien constitucionalmente compete la elaboración de los Presupuestos Generales del Estado, puede o no enmendar las cuantías y los fines a que tales gastos se destinan, decididos por la Mesa de la Cámara.

En opinión de L. M. Diez-Picazo el Gobierno (a quien compete la elaboración de los Presupuestos Generales del Estado, según el artículo 134 de la Constitución) puede modificar (sin perjuicio de las negociaciones previas que, en sede politica, pueden realizarse al respecto entre las Cámaras y el Ejecutivo) los anteproyectos de presupuestos de las Cámaras. Será un problema de corrección constitucional que el Gobierno acepte sin más el anteproyecto que le presente cada Cámara. En opinión del mencionado Profesor, para que no se vulnere el principio de autonomía de las Cámaras en la elaboración y aprobación de sus presupuestos, basta que la dotación presupuestaria de las Cámaras no esté sujeta al principio de especialidad presupuestaria en sentido cualitativo sino solamente en sentido cuantitativo. Al primero de ellos alude el artículo 42 LGP cuando establece que los créditos para gastos se destinarán exclusivamente a la finalidad específica para la que hayan sido autorizados por la Ley de Presupuestos Generales del Estado o por las modificaciones aprobadas conforme a esta Ley. Nos encontraríamos, entonces, ante una limitación cualitativa. Por su parte, los artículo 42 y 46 de la LGP prescriben que no podrán adquirirse compromisos de gasto por cuantía superior al importe de los créditos autorizados en los estados de gastos, siendo nulos de pleno derecho los actos administrativos y las disposiciones generales con rango inferior a la ley que infrinjan la expresada norma, sin perjuicio de las responsabilidades a que haya lugar. En este último caso, el criterio limitativo es de carácter cuantitativo.

Pues bien, la solución que propuso el Profesor L. M. Diez-Picazo iba en el sentido de que "los créditos para gastos de que puedan disponer las Cámaras sólo han de estar limitados por la cuantía total de sus dotaciones, sin que les sea 
exigible por el ordenamiento general del Estado y, consecuentemente, por la Ley de Presupuestos Generales del Estado que los destinen exclusivamente a finalidades o conceptos específicos. Por ello, las dotaciones que la Ley de Presupuestos asigna a las Cámaras no deben contener conceptos y, si lo hacen, deben reputarse simplemente indicativos y no vinculantes. Ello es una exigencia del artículo 72.1 de la Constitución que otorga a las Cámaras la prerrogativa de establecer autónomamente como van a realizar sus gastos. Problema distinto, como es obvio, es que el presupuesto de cada Cámara, a efectos internos de ésta, sí esté presidido por el principio de especialidad cualitativa y vincule a los órganos de la misma encargados del gasto" ${ }^{19}$.

Sin embargo, la larga cita transcrita contiene una elaboración doctrinal bastante discutible. Según su formulación, los créditos para gastos disponibles para las Cámaras sólo estarían limitados en la cuantía total de las dotaciones, pero no en el destino específico que se otorgase a los mismos. Varias cuestiones se suscitan en este punto, para cuya solución es necesario tener a la vista el bloque legal aplicable y la práctica seguida por los Poderes estatales:

- En primer lugar, la Constitución establece que las Cámaras aprueban autónomamente sus propios Presupuestos. (art. 72.1 CE).

- En segundo lugar, el Reglamento del Congreso dispone que corresponde a la Mesa elaborar el proyecto de Presupuesto del Congreso (art. $31.1 \mathrm{RCD}$ ).

De estas disposiciones se deduce, en nuestra opinión que la Mesa no está constitucionalmente constreñida o vinculada por ningún tipo de restricción cuantitativa o cualitativa. Ciertamente, que el documento que la Mesa aprueba es un proyecto de Presupuesto y que este proyecto no es ley hasta que no recae acuerdo final sobre el mismo del Pleno de la Cámara. Pero no es menos cierto que toda la gestación y tramitación del Presupuesto de las Cortes Generales se realiza sin intervención del Gobierno y, por tanto, sin obligación de dar cumplimiento en términos constitucionales a las limitaciones o directrices que en materia presupuestaria dicte el Gobierno para los restantes órganos constitucionales, Ministerios, organismos autónomos y empresas estatales. El Presupuesto de las Cortes Generales es, por tanto, el proyecto que aprueban las Mesas de las Cámaras, salvo que sea enmendado por los Grupos en sede parlamentaria, enmiendas que, en nuestra opinión, deben ser siempre negociadas con la Mesa, que es el órgano parlamentario a quien los Reglamentos confieren el gobierno interior y la gestión administrativa de la Cámara.

En conclusión la elaboración y aprobación de los presupuestos de las Cámaras, tanto del Congreso y Senado como de las Cortes Generales, se aprueban autónomamente por las Cámaras, sin intervención alguna del Gobierno que se limita a integrarlos en los Generales del Estado. Esta situación jurídica, que vie-

19 L. M. Diez-Picazo: La autonomía Administrativa de las Cámaras Parlamentarias. Op. Cit. Pág.130. 
ne refrendada, además, por la propia práctica parlamentaria, supone que se confiera la elaboración, aprobación, liquidación y control del Presupuesto a las propias Cámaras, sin intervención decisoria del Gobierno. Al Ministerio de Economía y Hacienda sólo corresponde, pues, integrar los Presupuestos remitidos por las Cámaras dentro de los Presupuestos Generales del Estado, donde - tal como puede apreciarse en los correspondientes al año 2007, aparecen incorporados como Sección 02 Cortes Generales, integrada por seis servicios ${ }^{20}$.

\section{5. ${ }^{\text {a) }}$ LOS COMPROMISOS PARLAMENTARIOS CON REFLEJO PRESUPUESTARIO}

Debemos, también mencionar como mecanismos de control parlamentario en el origen, cuantos 'compromisos' el Gobierno haya adquirido con 'reflejo presupuestario’ para el ejercicio siguiente, siempre que éstos sean consecuencia de iniciativas parlamentarias que habitualmente se mueven en la órbita de la información y del control: mociones, interpelaciones, preguntas y solicitudes de información. Por poner un ejemplo sencillo, puede perfectamente suceder que en una moción subsiguiente a una interpelación un Ministro comprometa una determinada inversión que, respaldada también por su propio Grupo Parlamentario, sea finalmente asumida por el Gobierno para el posterior ejercicio presupuestario. En el ejemplo reseñado, como consecuencia de una actividad genuina de control (la interpelación) se ha producido una iniciativa de impulso y dirección política (la moción), que no obliga jurídicamente al Gobierno, pero cuyo incumplimiento puede poner en tela de juicio su credibilidad política. De ahí, la pertinencia de su cumplimiento y de su inclusión en el proyecto de ley de presupuestos.

En otras ocasiones, el Gobierno deberá trasladar al Proyecto de Ley de Presupuestos los acuerdos extraparlamentarios alcanzados con las fuerzas sociales representativas de intereses específicos, a fin de que cobren eficacia jurídica. Tal sucede, en un ejemplo paradigmático, con los acuerdos alcanzados en la Mesa correspondiente en materia de crecimiento anual de los salarios para los empleados públicos. Negociado este crecimiento o, en su caso, por decisión del Gobierno, el Proyecto de ley incorporará la cifra de crecimiento de las retribuciones básicas de los empleados públicos, que será vinculante para todos los funcionarios de cualquier Administración, bien sea la central, la autonómica, la local o el personal al servicio de las llamadas $<<$ Administraciones independientes $>>$. El Tribunal Constitucional ha tenido ocasión de pronunciarse sobre el controvertido asunto de si las retribuciones incluidas en la Ley de Presupuestos vinculan a todas las Administraciones Públicas. En tal sentido, el supremo intérprete de la Constitución ha manifestado que "la imposición de

20 En efecto; si se comprueba, por ejemplo, la publicación de los Presupuestos Generales del Estado para el año 2007, veremos que allí aparecen incorporados los Presupuestos de las Cortes Generales, como Sección 02, integrada a su vez por cinco servicios: 01.- Cortes Generales; 02.- Congreso de los Diputados; 03.- Senado; 04.- Junta Electoral Central y 05.- Defensor del Pueblo. 
este tipo de topes máximos por parte del Estado halla justificación tanto en el título competencial contenido en el artículo 149.1.13 CE como en el principio de coordinación que opera como límite de la autonomía financiera de las CCAA (art. 156.1 CE) con el alcance previsto en el art. 2.1 b) LOFCA (SSTC 63/1986, 96/1990, 237/1992 у 103/1997).

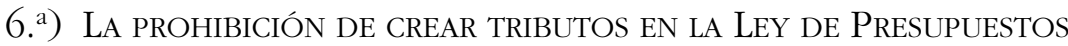

Una limitación adicional trae causa de la letra de la propia Constitución y es norma de aceptación común en el Derecho comparado. En concreto, el artículo 134.7 establece que "La Ley de Presupuestos no puede crear tributos. Podrá modificarlos cuando una ley tributaria sustantiva así lo prevea". Se trata, como puede apreciarse, de una prohibición general de crear nuevos tributos sin que vengan establecidos por una ley 'ad hoc', adecuadamente discutida y aprobada por la Cámara, o nuevas cargas sin la necesaria cobertura de una ley que le preceda. La proscripción del carácter innovador en materia de creación de tributos de la Ley de Presupuestos previsto en este apartado 7. ${ }^{\circ}$ del artículo 134 CE parece querer hacer rebrotar la vieja polémica del Presupuesto entendido sólo como ley en sentido formal.

\section{7. a) La VOtación del PRESUPUesto y la CONFIANZA PARLAMENTARIA: EL RECHAZO DEL PRESUPUESTO}

El significado político de la deliberación parlamentaria del Presupuesto y su eventual aprobación o rechazo por la Cámara expresa, paradigmáticamente, uno de los aspectos sustanciales de las relaciones entre Parlamento y Gobierno. $\mathrm{O}$, al menos así venía sucediendo en el parlamentarismo clásico de separación de poderes y equilibrio entre los mismos. El problema, así considerado, cobraba su plenitud en los sistemas parlamentarios de gobierno. En ellos, el programa político comprometido con los ciudadanos por el partido vencedor en las elecciones era sometido a una reactualización anual con ocasión de la elaboración discusión de los Presupuestos. Era el momento en el cual el programa político pasaba de ser una pura enunciación genérica a cobrar su factibilidad y aplicabilidad práctica a través de la concreta asignación de partidas para la consecución de determinados objetivos y fines sociales comprometidos con los ciudadanos.

Convenido, por tanto, que la elaboración y discusión del Presupuesto durante la fase del parlamentarismo puro era el debate político por excelencia, el más importante y determinante de cuantos tenían lugar anualmente en el Parlamento, la propia naturaleza política del debate y su incidencia en el equilibrio o desequilibrio de los Poderes exponía claramente a la luz pública dos cuestiones esenciales de las relaciones inter-orgánicas. La primera de ellas tiene que ver con la circunstancia de si un Gobierno dimisionario puede presentar el pro- 
yecto de Presupuesto ante el Parlamento. La segunda aludiría a la trascendental cuestión consistente en determinar las consecuencias jurídico-políticas de un voto contrario del Parlamento sobre el presupuesto.

\section{a) El Poder presupuestario del Gobierno en funciones}

Ha escrito el Profesor E. Guillén López que "puede afirmarse sin dudar que el problema principal del Gobierno cesante es la determinación de su margen e actuación así como de sus límites ${ }^{21}$. Pues bien, respecto de la primera cuestión planteada resulta inevitable afirmar que la naturaleza misma del debate que la presentación de los Presupuestos necesariamente provoca en la Cámara hace que un Gobierno dimisionario y en funciones este imposibilitado de proceder a tramitar ante la Mesa del Parlamento tan importante asunto y obligar a la Cámara a pronunciarse sobre tan solemne acto. Siquiera sea, en principio, porque el Presupuesto es la expresión cifrada de una política económica que se pretende ejecutar, situación que entra directamente en contradicción con el carácter efímero de un Gobierno situado en semejante trance constitucional.

Siendo así que el presupuesto es elaborado y presentado por un Gobierno que se responsabiliza de la tramitación parlamentaria y de la feliz conclusión de la misma, es evidente que esta responsabilidad no puede contraerla un Gobierno que haya renunciado por dimisión voluntaria de su titular. En efecto; si un gobierno dimisionario afrontase la discusión de los Presupuestos vendría a comprometer la dirección política que debería acometer, tras la solución de la crisis, el nuevo Gobierno resultante de la mayoría parlamentaria.

Es, por tanto, constitucionalmente absurdo pensar, todavía sólo en el plano exclusivamente teórico, que un Gobierno en tales circunstancias pueda tomar tal iniciativa y, aun más absurdo, que el Parlamento en cuestión aceptase el debate propuesto. De cualquier manera, la hipótesis analizada es sumamente teórica y es razonable presumir que nunca un Gobierno en funciones podría someter a discusión el Presupuesto en el Parlamento, la legitimidad no sólo en su fase primigenia de iniciativa devendría restringida ${ }^{22}$. No ya por un elemental deber de corrección jurídico constitucional y de utilidad política, sino porque en los periodos de crisis gubernamental el Parlamento suspende sus trabajos para atender con toda prontitud a una de las principales funciones que conserva todavía en el sistema parlamentario gobierno: la solución a la crisis y la creación de un nuevo Gobierno.

Si del plano general y abstracto de la especulación descendemos al Derecho Constitucional positivo español veremos que el artículo 101.1. ${ }^{\circ}$ de la Cons-

21 E. GuILLen LÓpez: El cese del Gobierno y el Gobierno en funciones en el ordenamiento constitucional español. Prólogo de P. HÄBERLE. Instituto Andaluz de Administración Pública. Consejería de Justicia y Administración Pública. Junta de Andalucía. Sevilla, 2002. Pág. 30.

22 Vid. F. REVIRIEgo Picón, El Gobierno cesante o en funciones en el ordenamiento constitucional español, BOE, Madrid, 2003, págs. 215-220. 
titución nos da cuenta de los supuestos de cese del Gobierno, mientras que el apartado $2 .^{\circ}$ configura expresamente el "Gobierno en funciones": 1.-«El Gobierno cesa tras la celebración de elecciones generales, en los casos de pérdida de la confianza parlamentaria previstos en la Constitución, o por dimisión o fallecimiento de su Presidente. 2.- El Gobierno cesante continuará en funciones hasta la toma de posesión del nuevo Gobierno".

Fácilmente se concluirá la imposibilidad de que el Gobierno en funciones tramite el Presupuesto. En el primero y tercero de los supuestos de cese contemplados en el artículo 101.1. ${ }^{\circ}$ (celebración de elecciones o dimisión o fallecimiento del Presidente) la Constitución ordena que el Rey consulte con los representantes políticos de las fuerzas políticas que hayan obtenido representación parlamentaria, a fin de proponer un candidato a Presidente que deberá superar la votación de investidura del Congreso de los Diputados (art. 99 CE). Además, en el primer caso (celebración de elecciones) hay que tener en cuenta que el mandato de los Diputados ha finalizado y que está en pleno ejercicio de sus poderes la Diputación Permanente hasta la Constitución de las nuevas Cortes (art. 78.2 en relación con el art. 68.6 CE). Y es evidente, por una parte, que el "Gobierno en funciones" sólo puede realizar actos de administración ordinaria para la atención imprescindible de las cuestiones inaplazables de gobierno, pero nunca que impliquen decisiones importantes de fondo. Y también, por otra parte, hay que dejar sentado que entre las competencias que la Constitución y el Reglamento del Congreso le atribuyen a la Diputación Permanente no figura la tramitación y aprobación del Presupuesto $^{23}$.

\section{b) El rechazo del Proyecto de Presupuesto por el Parlamento}

Pero en segundo lugar es posible que recaiga un voto negativo sobre el presupuesto por parte de una de las dos Cámaras del Parlamento o de ambas, dando así lugar al llamado "rechazo del Presupuesto". Esta hipótesis, desde luego perfectamente posible, constituye un momento sumamente grave desde el punto de vista de la dinámica política porque el bloqueo del Presupuesto por parte del Parlamento - junto con la moción de censura - supone la más palmaria manifestación de desconfianza del Parlamento sobre el Gobierno. Tal situación, dependiendo, desde luego, de que exista o no la figura de la "prorroga Presupuestaria", es susceptible por si misma de provocar perturbaciones evidentes en la vida política y administrativa del país. En consecuencia, la falta de aprobación del Presupuesto, desde la perspectiva estrictamente jurídica, al ini-

23 Sobre los problemas que aquí se apuntan, véase E. GunlLén López: La continuidad parlamentaria: Las Diputaciones Permanentes. Ed. Cívitas. Madrid. 2002; y también, del mismo autor, El cese del Gobierno y el Gobierno en funciones en el ordenamiento constitucional español. Instituto Andaluz de Administración Pública. Consejería de Justicia y Administración Pública. Junta de Andalucía. Sevilla. 2002. 
cio del nuevo ejercicio pondría al gobierno en la imposibilidad técnica de realizar cualquier gasto y de adquirir obligaciones y deberes frente a terceros, siempre, naturalmente, que no exista la institución de la "prorroga presupuestaria".

Convenimos, entonces, en que la aprobación del presupuesto constituye una necesidad objetiva para el funcionamiento del Estado y su ausencia crea un colapso en el funcionamiento institucional que el Derecho puede mostrarse manifiestamente impotente para resolver. Desde luego, las consecuencias jurídicas de un rechazo en bloque del Presupuesto no son iguales en todos los países. La dimensión del problema esta en función de la posición jurídica que el sistema de fuentes reserve a la Ley de Presupuestos. En tal sentido, en ciertos países el rechazo del Presupuesto por el Parlamento podría no tener consecuencias tan graves, siempre que subsistan créditos y el Tesoro pueda generar obligaciones estatales y las leyes consientan al Gobierno pagar de alguna manera los gastos estatales improrrogables.

Se ha discutido por la doctrina hasta que punto el Parlamento puede rechazar el Presupuesto cuando con ello crea una situación caótica en el país. Sin embargo, pero no parece objetable el hecho de que el Parlamento pueda votar negativamente en virtud de sus poderes esenciales atribuidos por la Constitución puesto que, si así fuese, el Parlamento vendría obligado a deliberar sobre un Presupuesto que, quizás, no tiene la más mínima intención de aprobar. Solamente un grave desacuerdo de naturaleza política podría admitir otra hipótesis, como demuestran casos verdaderamente excepcionales en la historia financiera de los Estados en los cuales se ha llevado a cabo un rechazo del Presupuesto. En algunos casos ello ha comportado la caída del Gobierno en su conjunto y en otros la salida del Gabinete del Ministro responsable del Presupuesto.

No siendo, desde luego, una situación habitual en el sistema parlamentario de Gobierno, sin embargo bien podría suceder que el Parlamento adoptase una de las medidas más contundente posible contra el Gobierno, es decir, la de negarse a aprobar el Proyecto de Ley de Presupuestos. Así como la aprobación del Proyecto sometido a conocimiento de la Cámara supone la conformidad de ésta con los objetivos políticos básicos contenidos en el Presupuesto, la negativa a la aprobación manifestaría un radical desacuerdo con los programas propuestos y las asignaciones consignadas.

El rechazo del Presupuesto por la Cámara y sus posibles consecuencias ha sido objeto de un amplio tratamiento doctrinal. Así, en la iuspublicística italiana, por ejemplo para Mortati, dicho rechazo constituye «la extremo ratio que el Parlamento opone al Gobierno en los sistemas no parlamentarios donde el Gobierno puede permanecer en el Poder sin la confianza de las Cámaras. En cambio, en el régimen parlamentario, basado en la confianza parlamentaria, el conflicto dimanante de la ruptura de la relación encontraría varias posibilidades de desbloqueo" ${ }^{24}$.

24 C. MORTATI, Istituzioni di diritto pubblico.Tomo II. Cedam. Padova. 1976. Págs. 674 y 675. 
Pues bien, en la doctrina se han debatido los efectos de la no aprobación por la Cámara de los presupuestos, en la medida en que ninguna norma de supremo rango excluye esta posibilidad. En tal caso habrá que estar a las consecuencias, pues aunque el rechazo del Presupuesto —o de parte del mismono comporta la dimisión automática del Gobierno, sí que puede dar paso a una crisis constitucional que, de prolongarse, concluya con la dimisión del Gobierno o con la disolución de las Cámaras. Si en Italia el conflicto se prolonga más allá del tiempo en que puede ser aplicado provisionalmente el Presupuesto ( 4 meses y previa autorización legal, según el art. 81 de la Constitución italiana) o si no se aprueba tal medida, el Profesor Pizzorusso entiende que cabe el recurso al Decreto Ley para adoptar las medidas imprescindibles hasta la disolución de las Cámaras ${ }^{25}$.

Tampoco en Alemania existe la prórroga presupuestaria constitucionalmente formalizada y el Gobierno Federal, llegado el caso de la no aprobación del Presupuesto del ejercicio siguiente, está facultado para realizar gastos de mantenimiento de compromisos o servicios legalmente preexistentes. (Art. 111 Ley Fundamental de Bonn). Y en Francia, si la Ley de Presupuestos no ha sido presentada en tiempo hábil para su promulgación antes del inicio del nuevo ejercicio económico, el Gobierno solicitará autorización urgente al Parlamento para percibir los impuestos y gastar los créditos por Decreto de los servicios votados. (Art. 47 Constitución francesa).

En nuestro texto constitucional vigente, el rechazo del Proyecto de Ley de Presupuestos no está vinculado a la permanencia o cese del Gobierno. En efecto, el artículo 101. 1 CE establece que "El Gobierno cesa tras la celebración de elecciones generales, en los casos de pérdida de la confianza parlamentaria previstos en la Constitución, o por dimisión o fallecimiento del Presidente». Por tanto, un rechazo de los Presupuestos no fuerza jurídicamente la dimisión del Gobierno ni del mismo son predicables los efectos prácticos de una moción de censura.

Pero, ello no significa que no pueda desencadenarse a partir de ese hecho una situación constitucional que desemboque en la dimisión del Gobierno, con su Presidente al frente, o en el planteamiento de una cuestión de confianza o, en último extremo, aconseje o imponga la propia disolución parlamentaria, dependiendo de la naturaleza política de la crisis. Para estas ocasiones la propia Constitución contempla la institución de la prórroga presupuestaria. En efecto el artículo 134.4 establece con toda claridad que "Si la ley de presupuestos no se aprobara antes del primer día del ejercicio económico correspondiente, se considerarán automáticamente prorrogados los Presupuestos del ejercicio anterior hasta la aprobación de los nuevos". Como bien se ha señalado por Valadés, una previsión de este tipo significa, sencillamente, que "para la oposición se atenúa el costo político de no aprobar los presupuestos y para el gobierno disminuyen las exigencias de negociar" ${ }^{26}$.

25 S. PIZZORUSSO, Lecciones de Derecho Constitucional. Tomo I. CEC. Madrid, 1984. Pág. 370.

26 D. VALADÉS, El control del Poder. Op. Cit. Pág. 287. 
Por consiguiente, la responsabilidad de los actores políticos en presencia disminuye, lo que puede propender a una menor voluntad de negociación que facilite el rechazo del Proyecto de Ley al no paralizarse la prestación de los servicios en virtud de la prórroga del Presupuesto anterior.

Sin embargo, no sería constitucionalmente admisible una prórroga de la prórroga, pues en tales condiciones en nuestro sistema parlamentario de gobierno se impone con urgencia la disolución gubernamental de las Cámaras a fin de que el pueblo recomponga una nueva mayoría capaz de afrontar con éxito la aprobación de unos nuevos presupuestos. La institución de la prórroga del Presupuesto anterior, en suma, no es sino una nueva explicitación de la posición reforzada del Gobierno en todo el ciclo presupuestario, pues pocas dudas ofrece que la posibilidad de acudir a la prórroga de los créditos aprobados en el ejercicio anterior priva al Parlamento de un arma de presión importantísima sobre el Gobierno al permitir que éste sobreviva, gestionando durante un cierto tiempo, en contra de la expresa voluntad de la Cámara.

Por último, debe tenerse en cuenta que la institución de la prórroga presupuestaria opera "en bloque" y no es constitucionalmente adminsible aprobar por Ley (que no sea la de Presupuestos) créditos que complementen a los ya prorrogados. Esta es la situación que se dio en el País Vasco con la Ley 1/2002, de 23 de enero, que, a juicio del tribunal Constitucional, vulneró el bloque de la constitucionalidad aplicable al Presupuesto. En efecto, el Tribunal Constitucional vino a declarar que la mentada Ley, conviviendo con los Presupuestos prorrogados para el ejercicio de 2002, "produce una fragmentación de la institución presupuestaria que es contraria a los principios de unidad y universalidad presupuestaria, esto es, a la exigencia de que el Presupuesto se contenga en un único documento que incluya la totalidad de ingresos y gastos del sector público". (STC 3/2003, F. J. 9).

\section{LA ACTIVIDAD DE CONTROL EN LA EJECUCION DEL PRESUPUESTO}

Los Estatutos de las diversas Comunidades Autónomas han sido más precisos a la hora de regular las atribuciones del Parlamento y del Gobierno en el ciclo presupuestario. A pesar de ello, y aunque la Constitución expresamente no lo signifique, del juego combinado de los artículos 66.2 y 134.1 CE no puede deducirse sino que corresponde a las Cortes Generales el control de los Presupuestos en fase de ejecución, sin perjuicio de que a tal efecto se auxilie de un órgano técnico que no es otro que el Tribunal de Cuentas.

Descendiendo al plano de la legalidad ordinaria, el artículo 74 LGP establece que "Corresponde a los Órganos constitucionales, a los Jefes de los Departamentos ministeriales y a los demás órganos del Estado con dotaciones diferenciadas en los Presupuestos Generales del Estado aprobar los gastos propios de los Servicios a su cargo, salvo los casos reservados por la Ley a la competencia del Gobierno, así como autorizar su compromiso y liquidación, e 
interesar del Ministerio de Economía y Hacienda la ordenación de los correspondientes pagos". Similares preceptos se contienen en las diversas leyes que regulan la Hacienda Pública de las respectivas Comunidades Autónomas. Aunque la Constitución guarde silencio al respecto (no así los Estatutos de Autonomía). Podemos concluir, por tanto, que la ejecución y liquidación del Presupuesto es una competencia del Gobierno cuyo control, mediato o inmediato, corresponde al Parlamento.

Necesario resulta precisar en este punto que el artículo 136 de la Constitución crea el Tribunal de Cuentas, que viene definido como "supremo órgano fiscalizador de las cuentas y de la gestión económica del Estado, así como del sector público". El citado Tribunal depende directamente de las Cortes Generales y actúa por delegación de éstas en el examen y comprobación de la Cuenta General del Estado. Sin perjuicio de su actividad jurisdiccional, el Tribunal de Cuentas remite a las Cortes Generales un informe anual en el que pone de manifiesto las responsabilidades e irregularidades que hubiese detectado en su actividad fiscalizadora. Y similares órganos, y a los mismos efectos de control externo, han sido creados en las Comunidades Autónomas, en el marco de sus competencias y en colaboración y coordinación con el Tribunal de Cuentas cuya función fiscalizadora se extiende, en principio, a todo el territorio nacional y cuyo engarce institucional, delimitación competencia y armonización funcional con las figuras semejantes de carácter autonómico ha sido esclarecido por la jurisprudencia constitucional (STC 187/1988, de 17 de octubre y STC18/1991, de 31 de enero).

Pero, no forman parte del objeto de nuestro estudio la naturaleza y funcionamiento de los órganos de control externo del Presupuesto, por más que éstos dependan de las propias instituciones parlamentarias. También en fase de ejecución y liquidación nuestro trabajo se contrae a detectar la actividad de control que acaece intramuros de la Cámara. Debemos, pues, examinar las acciones más importantes que despliega el órgano parlamentario una vez aprobados y en vigor los Presupuestos Generales del Estado.

\section{1. $\left.{ }^{a}\right)$ LAS MODIFICACIONES PRESUPUESTARIAS A INSTANCIAS DEL GOBIERNO}

Debemos reparar, en primer lugar, en que una vez aprobado el Presupuesto, la propia Constitución establece la posibilidad de que el Parlamento modifique los Presupuestos a iniciativa del Gobierno, según recoge el artículo 134.4 CE. Conforme a la literalidad de este artículo, «aprobados los Presupuestos Generales del estado, el Gobierno podrá presentar proyectos de ley que impliquen aumento del gasto público o disminución de los ingresos correspondientes al mismo ejercicio presupuestario". Es evidente que por la propia naturaleza, contenido y función de la Ley de Presupuestos, el mencionado art. 134.5 no autoriza a que cualquier norma modifique, sin limitación alguna, la autorización que el Parlamento ha concedido así como el destino de esos gastos que la Ley establece. 
La alteración de esa habilitación y, por su conducto, del programa político que se pretende ejercitar sólo puede llevarse a término en supuestos excepcionales, concretamente cuando se trate de un gasto inaplazable derivado de circunstancias sobrevenidas. Admitir la alteración indiscriminada de las previsiones de la Ley de Presupuestos a través de otra ley posterior supondría tanto como vaciar de contenido los principios de anualidad y universalidad presupuestarias contenidos en el art. 134.2 CE. Así lo ha entendido la Constitución en su art. 134.5 cuando el legislador estatal autoriza al Gobierno a solicitar de las Cortes un crédito extraordinario o un suplemento de crédito sólo cuando exista «algún gasto que no pueda demorarse hasta el ejercicio siguiente y no exista en los Presupuestos del estado "crédito o sea insuficiente y no ampliable el consignado y se especifique el recurso que haya de financiar el mayor gasto público" (art. 51 LGP).

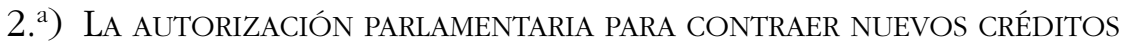 O DISMINUIR LOS INGRESOS}

Una segunda limitación general viene también recogida en la propia Constitución, cuando taxativamente se ordena que el Gobierno no puede contraer créditos si no está previamente autorizado por ley de las Cortes Generales (art. 135.1). Por cuanto el Gobierno tiene constitucionalmente atribuida la dirección de la política económica del Estado, puede verse en la necesidad de adoptar decisiones que impliquen un mayor gasto público o una reducción de las fuentes de financiación que precisa para obtener esos recursos. Por ello, una vez que han sido aprobados los Presupuestos Generales del Estado, también es la propia Constitución la que le habilita para presentar ante las Cortes proyectos de ley que impliquen aumento de gasto público o disminución de ingresos correspondientes al mismo ejercicio presupuestario. Este incremento en los programas de inversión pública o reducción de la presión fiscal, en su caso, son decisiones de pura oportunidad política que el Gobierno adopta en ejercicio de competencias constitucionalmente atribuidas, y cuya aprobación obtendrá sin dificultad en el Parlamento de la mano de la mayoría que le apoya y respalda en la Cámara.

\section{3. a) La tramitación de Proposiciones de LEy y LA PRESENTACión DE ENMIENDAS A TEXTOS LEGISLATIVOS QUE IMPLIQUEN AUMENTO DE GASTOS O DISMINUCIÓN DE INGRESOS}

Por las mismas razones antes apuntadas, el Gobierno acometerá el ejercicio de la política económica anual, en principio, con los créditos que tiene aprobados en la Ley de Presupuestos del ejercicio de que se trate. Pero, nada impide que los sujetos que ostentan la titularidad de la iniciativa legislativa distintos al Gobierno (en particular, los Grupos Parlamentarios de la oposición), pre- 
senten a lo largo de los periodos de sesiones del ejercicio presupuestario Proposiciones de Ley o enmiendas a textos legislativos que impliquen aumento de gastos o disminución de ingresos del Presupuesto en vigor.

Si ello sucediera, el Gobierno tiene la facultad constitucional de oponerse o, en su caso, otorgar la conformidad a la tramitación de los mismos. Todo ello, en consonancia con sus facultades constitucionales de director de la política interior y exterior, de la Administración civil y militar y de la Defensa del Estado (art. $97 \mathrm{CE}$ ). La función de dirección política que ostenta el Gobierno tiene como contrapartida que los poderes del Parlamento en materia presupuestaria están estrictamente tasados. De ahí resulta una consecuencia lógica para el Gobierno: si éste ha de ejecutar el Presupuesto aprobado por el Parlamento, congruente resulta con dicha encomienda que goce de los pertinentes mecanismos de defensa ante presuntas alteraciones de las cuantías procedentes de actos o iniciativas de la propia Cámara. De esta inicial coherencia que se espera del Parlamento, a favor de sus propios actos previos, resulta una prerrogativa a favor del Gobierno, a la que los Profesores J. García Morillo y P. Pérez Tremps han llamado la potestad de "veto presupuestario", regulada en los artículos 134.6 CE y 111 y 126.2 y $3 \mathrm{RCD}^{27}$.

Se trata, a la postre, de mecanismos tendentes a evitar la desviación presupuestaria, una vez que el Gobierno ha obtenido del Parlamento la autorización para la ejecución de unas determinadas prioridades en materia de política económica. Por ello, las facultades del Gobierno para oponerse a la admisión a trámite de una proposición de ley o de una enmienda que comporte aumento de créditos o disminución de ingresos no confiere al Ejecutivo un trámite de obligada consulta por la Mesa, que ésta vendría obligada a evacuar y que no resulta vinculante. Antes al contrario, la Constitución y el Reglamento del Congreso confieren al Gobierno una auténtica capacidad de veto para bloquear la admisión de iniciativas que perturben la ejecución presupuestaria que tiene encomendada por la Cámara.

\section{$\left.4 .^{a}\right)$ LAS INICIATIVAS PARLAMENTARIAS DE SEGUIMIENTO DE LA ACTIVIDAD PRESUPUESTARIA DEL GOBIERNO}

Una tercera e inmediata actividad de control sobre la ejecución del Presupuesto se efectúa a través de los mecanismos ordinarios de seguimiento y evolución de la política del Gobierno: es decir, la presentación y tramitación de interpelaciones, preguntas (orales o escritas) y solicitudes de información. Las dos primeras permitirán conocer no sólo los datos y cifras de la ejecución sino también las intenciones, preocupaciones, dificultades o facilidades que el Gobierno y la Administración han encontrado para ejecutar una determinada par-

27 Vid. J. GARCIA MORILLO y P. PEREZ TREMPS: Legislativo VS. Ejecutivos autonómicos: El problema del veto presupuestario. Parlamento y Cortes. Cortes de Castilla-La Mancha, Toledo, 1998. 
tida presupuestaria; las solicitudes de información por escrito facilitarán, en cambio, el acceso a datos, informes o documentos que obren en poder de las Administraciones públicas, sin que de ordinario incluyan valoración política alguna sobre el estado de los créditos en la contestación que remite el Gobierno.

En este mismo apartado habría que incluir las comparecencias en sesiones informativas, generalmente ante la Comisión correspondiente por razón de la materia, de los titulares de los distintos Departamentos a los mismos fines anteriormente citados. Valga como ejemplo, a tal respecto, la previsión establecida en el artículo 10.3 de la Ley 21/1993, de 29 de diciembre, de Presupuestos Generales del Estado para 1994, cuando prescribe que «El Gobierno comunicará trimestralmente a las Comisiones de Presupuestos del Congreso y del Senado las operaciones de ejecución del Presupuesto del Estado realizadas en dicho periodo de tiempo, a los efectos de acreditar el cumplimiento de la obligación prevista".

\section{5. a) LAS AUTORIZACIONES PARLAMENTARIAS PARA OPERACIONES PRESUPUESTARIAS ESPECIALMENTE CUALIFICADAS}

En quinto lugar hay que consignar que la Ley General Presupuestaria somete a aprobación previa del Parlamento determinadas autorizaciones para efectuar ciertas operaciones especialmente cualificadas. Así, por ejemplo:

- El establecimiento — si no figurasen en los Presupuestos Generales del Estado- y, en todo caso, la modificación del crédito de acción coyuntural precisa de la remisión a las Cortes Generales de un proyecto de ley y de una memoria explicativa, a fin de que por las Cámaras se autoricen y concreten las inversiones que se pretenden realizar. Igualmente, el Gobierno deberá dar cuenta anualmente a las Cortes Generales de la aplicación del crédito de acción coyuntural.

- Salvo que la ley lo autorice de modo expreso, los `derechos' liquidados y las 'obligaciones' establecidas se aplicarán a los presupuestos por su importe integro, estando prohibido atender obligaciones mediante minoración de los derechos a liquidar o ya ingresados.

- Cuando no exista en el Presupuesto crédito o éste sea insuficiente y no ampliable y el Gobierno deba acometer algún gasto que no admite demora, se remitirá un proyecto de ley a las Cortes de concesión de un crédito extraordinario o, en su caso, de un suplemento de crédito en el que quede claramente especificado el objeto de financiación que implica ese mayor gasto público. El Gobierno dará trimestralmente cuenta a las Cortes Generales de los créditos extraordinarios y suplementos de crédito concedidos, con al menos el mismo y preciso detalle que contuviera el Presupuesto.

- El Gobierno precisa de autorización legal para emitir deuda pública (art. 135.1 CE). En consecuencia, la utilización de este instrumento, tanto por 
el Estado como por los organismos autónomos, requerirá autorización previa del Parlamento mediante ley que señalará el importe máximo autorizado. El pago de intereses y capital de la misma deberán estar incluidos en el estado de gastos de los Presupuestos y no podrán ser enmendados o modificados siempre que se ajusten a su ley de creación (art. 135.2 CE).

- El Gobierno debe comunicar, con carácter trimestral, a las Comisiones de Presupuestos del Congreso y del Senado el saldo detallado en la cuenta de las operaciones del Tesoro que supongan instrumentos de financiación a plazo inferior a un año (emisiones de Letras del Tesoro, líneas de crédito especiales etc.).

En general, similares controles parlamentarios se contienen en las Leyes que regulan la Hacienda Pública de las distintas Comunidades Autónomas, en el marco de sus propias competencias y con las especificaciones que las mismas han podido o querido introducir. Pero, enseguida hay que añadir que estas restricciones y controles, con ser muy importantes, no son asfixiantes para la Administración, pues la propia Ley General Presupuestaria (o las distintas Leyes de Hacienda Pública de las Comunidades Autónomas) habilitan al Gobierno para efectuar 'modificaciones presupuestarias' mediante transferencias de créditos y 'generaciones', 'incorporaciones' y 'ampliaciones' de crédito, siempre, naturalmente, en los supuestos y con los requisitos previstos en la legislación presupuestaria.

De todas estas operaciones y de otras que el Gobierno adopte (por ejemplo, concesión de avales, subvenciones, emisión de deuda pública etc.) se da cuenta periódicamente a la Comisión de Hacienda correspondiente. A ella se remite la pertinente documentación al efecto, produciéndose la inclusión en el orden del día de la Comisión y el subsiguiente debate, en su caso. Por aludir, en concreto, a la Comisión de Presupuestos del Congreso de los Diputados y ya desde la V Legislatura, auspiciado por la Presidencia de la misma se adoptó un acuerdo político por el que el Gobierno se comprometía a suministrar periódicamente amplia documentación e información en materia de ejecución presupuestaria. A salvo las correspondientes prescripciones de la Ley General Presupuestaria, debe precisarse que el mencionado acuerdo obedece a una suerte de convención parlamentaria que obliga en tanto las partes que la suscriben se sienten vinculadas por la misma. No nos consta, por lo demás, que hasta la fecha se haya dictado una Resolución de la Presidencia del Congreso en orden a regular el contenido, debate y forma de esta información.

Resulta evidente, por lo demás, que de todo el arsenal de comparecencias parlamentarias y de documentación de diverso tipo, aportada a los miembros de la Comisión de Presupuestos en materia de ejecución presupuestaria, surgen a su vez nuevas iniciativas parlamentarias en un efecto de retroalimentación indudable. Y ello porque la actividad informativa es un paso previo y necesario para una adecuada actividad de control, pues aunque aquélla pueda agotarse en sí misma, lo usual es que sobre la información recibida se realice una acti- 
vidad de valoración y apreciación, un juicio de carácter crítico que provendrá, lógicamente, de los diputados y Grupos que integran la oposición parlamentaria.

\section{6. ${ }^{a}$ La ejecución y liQuidación del Presupuesto de las Cortes Generales}

Como una consecuencia ineludible del principio de autonomía presupuestaria de las Cortes Generales garantizado por el artículo 72.1 de nuestro texto constitucional, el artículo 31.2 del Reglamento del Congreso de los Diputados establece que corresponde a la Mesa "dirigir y controlar" la ejecución del Presupuesto del Congreso y "presentar ante el Pleno de la Cámara, al final de cada ejercicio, un informe acerca de su cumplimiento". Por su parte, aunque el Reglamento del Senado guarda silencio al respecto, en la práctica la cuestión se desenvuelve en los mismos términos que en la Cámara Baja en virtud de las competencias generales que la Mesa posee en materia de gobierno y régimen interior de la institución.

Esta fase de ejecución presupuestaria ha sido calificada por el Profesor L. M. Diez-Picazo, con todo acierto, como «una de las piedras angulares de la autonomía administrativa de las Cámaras, ya que su correcta articulación permite que, sin perjuicio de la unidad patrimonial del Estado-aparato y de que se imputen a éste como persona jurídica unitaria las relaciones ad extra establecidas por cualquiera de sus órganos, las Cámaras pueden entablar (disponiendo autónomamente de sus gastos) dichas relaciones con terceros, independientemente del Gobierno y la Administración ${ }^{28}$.

Como consecuencia de lo anterior, los órganos competentes para la autorizar el gasto en el interior de la propia Cámara es la Mesa correspondiente. En efecto, el Reglamento del Congreso de los Diputados establece que corresponde a la Mesa "ordenar los gastos de la Cámara, sin perjuicio de las delegaciones que pueda acordar" (art. 31.3. ${ }^{\circ}$ RCD). Ello significa que esta disposición de fondos, estatales al fin y al cabo, corresponde al máximo órgano de gobierno interior de la Cámara, sin perjuicio de que el Presidente, al que viene conferida la representación de la misma, otorgue su firma para la mencionada disposición. La posible responsabilidad por el incumplimiento de estas normas es también de carácter interno, ello sin perjuicio de que en el correspondiente procedimiento contencioso-administrativo fuese anulada la disponibilidad del crédito correspondiente si éste no hubiese sido efectuado por la Mesa como órgano competente.

Una vez autorizado el gasto por la Mesa de la Cámara, el procedimiento continúa con el acto de la ordenación del pago. En concordancia, también, con el mencionado principio de autonomía presupuestaria, la autorización y disposición sobre el gasto de las correspondientes partidas también corresponde

28 L. M. DIEZ-PICAZO: La autonomía Administrativa de las Cámaras parlamentarias. Op. Cit. pág. 131 y 132. 
internamente a las Cámaras, pues «el Presidente ordena los pagos, sin perjuicio de las delegaciones que pueda conferir" (art. $32.1 \mathrm{RCD}$ ), facultad esta que no es sino una particularización de la más general contenida en la propia Constitución cuando afirma que "Los Presidentes de las Cámaras ejercen en nombre de las mismas todos los poderes administrativos..." (art. $72.3 \mathrm{CE}$ ).

La autonomía de las Cámaras implica que, una vez autorizado el gasto por el órgano correspondiente, el pago se efectúe por la Presidencia de la Cámara, acto éste que ha sido puesto en cuestión al entender que los pagos "se extralimitan de lo que es puramente interno e inciden en una materia a todas luces propia del ordenamiento general...sobre todo si se tiene en cuenta que el gasto de las Cámaras no está sujeto a control preventivo...ni a control consunti$v o . . .2^{29}$. Este punto requiere, al menos, también una breve reflexión.

De una parte, el artículo 148 de la Ley General Presupuestaria (LGP), al disponer del régimen de control interno ejercido por la Intervención, establece que "todos los actos, documentos y expedientes de la Administración del Estado de los que se derivan derechos y obligaciones de contenido económico, serán intervenidos y contabilizados con arreglo a lo dispuesto en la presente Ley y en sus disposiciones complementarias". En consecuencia, la LGP sólo somete a intervención previa del gasto a la Administración civil y militar, no incluyendo, por tanto, a la Administración parlamentaria.

De otra parte, el Tribunal de Cuentas, en cuanto supremo órgano fiscalizador del sector público estatal, no comprende entre sus competencias la fiscalización y control de los gastos de las Cámaras, pues el artículo 4 de la Ley Orgánica 2/1982, de 12 de mayo, del Tribunal de Cuentas, al delimitar su ámbito fiscalizador, establece que integran el sector público la Administración del Estado, las Comunidades Autónomas, las Corporaciones Locales, las entidades gestoras de la Seguridad Social, los Organismos Autónomos y las Sociedades estatales y demás Empresas públicas. Como bien puede apreciarse, no existe rastro alguno de las Administraciones parlamentarias. No hay, pues, vinculación alguna al control preventivo ni al control consuntivo y no rige el principio de especialidad presupuestaria, ni en sentido cuantitativo ni en sentido cualitativo.

En conclusión, podemos afirmar que las Cámaras parlamentarias en España, siguen un sistema de autorización del gasto y de ordenación de los pagos de manera interna y regido por el Reglamento parlamentario y por las disposiciones internas que por el órgano competente (Presidencia o Mesa) puedan dictarse en cada momento. Sólo de manera supletoria, y en aquellas cuestiones que no colisionen con la normativa interna, puede regir el procedimiento de gasto y el régimen general de ordenación de pagos previsto en la LGP. Lo que no deja de ser coherente y consecuente con el principio de autonomía presupuestaria garantizado por el artículo 72.1 de la Constitución. 


\section{7.a) El CONTROL DE LOS < FONDOS RESERVADOS>}

Aludimos, por último al control de los $<<$ fondos reservados $>>$, por el preciso y controvertido sentido que estos poseen. Por ello han merecido un trato especial por parte del legislador los créditos destinados a ciertas operaciones en materia de seguridad interior y exterior, donde han cobrado celebridad los llamados $<<$ fondos reservados $>>$.

Siguiendo al Profesor J. Cano Bueso ${ }^{30}$ es necesario poner de manifiesto que se trata de partidas presupuestarias destinadas a obligaciones financieras cuyo conocimiento público podría poner en peligro aspectos relevantes relacionados con la seguridad y defensa nacional. Regulados en la Orden Ministerial de 1 de marzo de 1985, sobre elaboración de los Presupuestos Generales del Estado para 1986, y por Resolución de la Dirección General de Presupuestos, de 15 de marzo de 1985, han sido centro de polémica y controversia parlamentaria y judicial. La discusión sobre la razón de su existencia y el control de su destino ha provocado interminables debates parlamentarios y ríos de tinta en los medios de comunicación.

No es correcto decir que las partidas que nos ocupan estuvieron siempre desprovistas de cobertura legal, sin perjuicio de convenir en que ésta no era la adecuada. Estos gastos tuvieron inicialmente su apoyo legal en la Ley 9/1968, de 5 de abril, modificada por la Ley 48/1978, de 7 de octubre, de Secretos Oficiales (LSO), donde se establece el criterio general de que la actividad de los órganos del Estado está sujeta al principio de publicidad, con excepción de los casos en que la materia sea declarada 'clasificada' por razón de la naturaleza de la misma. En virtud de dicha Ley, podían ser declaradas 'materias clasificadas' los asuntos, actos, documentos, informaciones, datos y objetos cuyo conocimiento por persona no autorizada pueda dañar o poner en riesgo la seguridad y defensa del Estado (art. 2). Y los efectos de la mencionada 'declaración' se establecían en el artículo 13: "Las actividades reservadas por declaración de Ley y las 'materias clasificadas' no podrán ser comunicadas, difundidas ni publicadas, ni utilizar su contenido fuera de los límites establecidos por la Ley. El incumplimiento de esta limitación será sancionado, si procediere, conforme a las Leyes penales y por vía disciplinaria, en su caso, considerándose en este último supuesto la infracción como muy grave".

Pero es lo cierto que, si nos fijamos con atención, el artículo 10.2 de la LSO levanta la limitación para el Congreso y el Senado, "que tendrán siempre acceso a cuanta información reclamen, en la forma que determinen los respectivos Reglamentos y, en su caso, en sesiones secretas". Actualmente está en vigor la Resolución de la Presidencia del Congreso de los Diputados sobre secretos oficiales de 11 de mayo de 2004. En ella se establece que sólo los Grupos Parlamentarios que representen, al menos, la cuarta parte de la Cámara pueden re-

30 J. CANO BUESO. "Información parlamentaria y secretos oficiales". Revista de las Cortes Generales. N. ${ }^{\circ}$ 42. Tercer cuatrimestre, 1997. Págs. 3 a 34. 
cabar por conducto de la Presidencia información sobre materias clasificadas. El Gobierno posibilitaría el acceso a la información dependiendo del nivel de clasificación: si la materia se declaraba 'secreta' accedería a la misma un Diputado por cada Grupo Parlamentario, de los constituidos con arreglo a lo previsto en el artículo 23.1. ${ }^{\circ} \mathrm{RCD}$ y elegidos por el Pleno por mayoría de tres quintos; si la clasificación era sólo 'reservada' podían acceder a la misma todos los Portavoces de los Grupos Parlamentarios, incluidos los de la Comisión correspondiente; si el nivel de clasificación, en fin, era 'supersecreto', accedería a la misma, exclusivamente, el Presidente del Congreso de los Diputados o el de la Comisión correspondiente.

Visto cuanto antecede, y por lo que aquí nos ocupa —que son los créditos destinados a 'gastos reservados'-, el artículo 1.2 de la Ley de Secretos Oficiales establecía que "Tendrán carácter secreto, sin necesidad de previa clasificación, las materias así declaradas por Ley", en este caso, la Ley de Presupuestos Generales del Estado para el ejercicio correspondiente. Su polémico control, por lo demás, hubiera sido posible a través de la vía establecida en la Resolución de la Presidencia del Congreso de los Diputados citada. A fin de evitar las controversias de todo tipo y la crítica política que de la falta de control sobre los mismos había existido, las Cortes Generales aprobaron la Ley 11/1995, de 11 de junio, reguladora de la Utilización y Control de los Créditos destinados a Gastos reservados, cuyo artículo 1 definía qué debía entenderse por tales: "Tienen la consideración de fondos reservados los que se consignen como tales en las Leyes de Presupuestos Generales del Estado y que se destinen a sufragar los gastos que se estimen necesarios para la seguridad y defensa del Estadon. Dichos gastos se caracterizan por la prohibición de publicidad y por su clasificación de 'secreto' en los términos ya citados de la LSO vigente (art. 3). Sólo tres Ministerios podrán disponer de ellos Exteriores, Interior y Defensa y sus titulares deberán dar cuenta periódica de su utilización al Presidente del Gobierno (art. 4). Por lo que se refiere a su control parlamentario, se crea una Comisión 'ad hoc', presidida por el Presidente del Congreso e integrada por los Diputados que, de conformidad con la Resolución de la Presidencia del Congreso ya citada, tengan acceso a los `secretos oficiales' (art. 7). Ante ella, y con carácter semestral, deberán los titulares de los Departamentos aludidos informar sobre el uso de dichos fondos. Las sesiones tendrán carácter secreto y los Diputados vienen obligados a no divulgar el contenido de las mismas, en los términos del artículo $16 \mathrm{RCD}\left(\operatorname{art} .7 .2 .^{\circ}\right.$ y $3 .^{\circ}$ ).

Atendida la delicadeza de las partidas disponibles para este especial gasto, La Ley arbitra un procedimiento singular de justificación de estos créditos y las modificaciones presupuestarias que supongan aumento de los mismos sólo podrán ser aprobadas por las Cortes Generales, previo informe de la Comisión ‘ad hoc' (art. 2, 5 y 6). Las autoridades que dispongan, en fin, de este tipo de fondos deberán realizar ante el Presidente del Congreso una declaración especial sobre su situación patrimonial, que sólo podrá ser conocida por los miembros de la Comisión mencionada (Disposición adicional y única). Por último, preciso resulta recordar en este punto que los créditos destinados a 'gastos reserva- 
dos' tendrán, en todo caso, carácter vinculante, con el nivel de desagregación con que aparezcan en los estados de gastos (art. 59.3 LGP).

ABSTRACT. Modern democratic States, forged around the nuclear idea of a written Constitution as an instrument for the limitation of Power, have in time shaped the principles of control and responsibility as elements that are inherent to the very idea of democracy. It is typical and substantial of a democratic state to adopt a Constitution and to emerge in law ordination as a limited state, endowed with responsible public powers subjected to a control over its decisions that is exerted by those who represent the public will. With the passing of time, these notions of responsibility and account rendering have constructed a theory for the control of constitutional organisations and the activity of Public Administration itself, which have represented, to a great extent, the foundations of the Rule of Law. The ways and means in which this control has been constitutionalised or legalised are many and varied, depending to a certain extent on evolution from an absolute state to a constitutional state, later undergoing profound transformations, ending in the current social and democratic state of the present constitutions of the countries that integrate the European Union, where control and responsibility are today mutually assumed concepts. This research work seeks to verify the adequacy of certain behaviours with regard to political mandate and legal ordination, according to the different cases, in which any form of inadequacy meets with implicit or explicit sanction or reprobation. As the state has become more democratic, this control has become more sophisticated. Thus, one of its specialisations has given rise to political parliamentary control over the Budget and financial economic control over the Public sector of the state. 